\title{
New and emerging therapeutic options for malignant pleural mesothelioma: review of early clinical trials
}

This article was published in the following Dove Press journal:

Cancer Management and Research

23 January 2015

Number of times this article has been viewed

\author{
Svetlana Kotova ${ }^{1,2}$ \\ Raymond M Wong ${ }^{1-3}$ \\ Robert B Cameron ${ }^{1,2}$ \\ 'Veterans Affairs Greater Los Angeles \\ Healthcare System, Division of \\ Thoracic Surgery, Los Angeles, CA, \\ USA; ${ }^{2}$ UCLA Division of Thoracic \\ Surgery and Comprehensive \\ Mesothelioma Program, Los Angeles, \\ CA, USA; ${ }^{3}$ Pacific Meso Center at \\ the Pacific Heart, Lung and Blood \\ Institute, Los Angeles, CA, USA
}

\begin{abstract}
Malignant pleural mesothelioma (MPM) is a rare tumor that is challenging to control. Despite some benefit from using the multimodality-approach (surgery, combination chemotherapy and radiation), survival remains poor. However, current research produced a list of potential therapies. Here, we summarize significant new preclinical and early clinical developments in treatment of MPM, which include mesothelin specific antibody and toxin therapies, interleukin-4 (IL-4) receptor toxins, dendritic cell vaccines, immune checkpoint inhibitors, and gene-based therapies. In addition, several local modalities such as photodynamic therapy, postoperative lavage using betadine, and cryotherapy for local recurrence, have also shown to be effective for local control of disease.
\end{abstract}

Keywords: MPM, new targeted, systemic, local therapies

\section{Introduction}

Malignant pleural mesothelioma (MPM) is a rare asbestos-induced malignancy with an estimated incidence of approximately 2,180 new cases diagnosed in the United States in $2013 .{ }^{1}$ Approximately $30 \%$ of US cases are diagnosed among veterans, and $20 \%$ are seen in women. Worldwide, nearly $80 \%$ of mesothelioma deaths occur in ten countries, with the United Kingdom, United States, and Japan being in the top three. ${ }^{2}$ While peak incidence of MPM in the US has been reached, worldwide it is expected to continue to increase over the next several decades. ${ }^{3}$ Median survival ranges from 9-18 months and correlates with stage..$^{4,5}$

\section{Currently established therapy Chemotherapy}

Pemetrexed and cisplatin combination therapy was established as a standard treatment for mesothelioma patients who are not surgical candidates after a landmark multicenter randomized Phase III trial of 456 patients. ${ }^{6}$ The trial demonstrated a nearly 3 -month survival benefit, with median survival of 12.1 months versus 9.3 months for patients treated with cisplatin alone. Tumor response was seen in $41.3 \%$ of the 226 pemetrexed and cisplatin treated patients and $16.7 \%$ of the 222 patients receiving cisplatin alone.

\section{Surgical resection}

The theoretical goal of surgical resection is to achieve complete tumor removal (R0 resection), which in reality is virtually impossible. A more realistic goal is to achieve an $\mathrm{R} 1$ resection with only microscopic residual disease. 
While the Mesothelioma And Radical Surgery (MARS) feasibility trial showed that few patients qualified for surgery and the outcomes did not support extrapleural pneumonectomy (EPP), ${ }^{7}$ surgery is offered to select patients in high volume centers with specific interest in mesothelioma, and it may offer a survival advantage. EPP was formerly thought to produce better survival than pleurectomy and decortication (P/D) but as more evidence accumulates $\mathrm{P} / \mathrm{D}$ actually may offer a better survival. ${ }^{5,8}$ Indirect evidence supporting this comes from work by Flores et al, ${ }^{5}$ who observed overall survival of only 10.2 months in patients who did not undergo any surgery and 14.0-15.8 months in those who underwent resection.

\section{Radiation}

Radiation has been used for either gross tumor (palliative intent) or for adjuvant local control in the postoperative setting in an attempt to control the residual microscopic disease that is nearly universally present following any surgical resection. The ability to administer effective doses of radiation to the large surface area of the pleural space, particularly following $\mathrm{P} / \mathrm{D}$ with the lung in place, is quite challenging. Consequently, the broadest application of postoperative radiation has been in patients following EPP since the ipsilateral lung is removed. However, the risk for toxicity to the adjacent organs (heart, spinal cord and liver, esophagus) remains. Despite the theoretically lower risk of pulmonary toxicity, radiation following EPP was associated with a nearly $20 \%$ incidence of severe pneumonitis in the contralateral lung in at least one study. ${ }^{7}$

Several groups have described use of radiation in patients after ipsilateral lung preservation with $\mathrm{P} / \mathrm{D}$ with an acceptable toxicity profile (summarized in Table 1). Thus newer techniques, such as tomotherapy, ${ }^{9,10}$ which are able to deliver a circumferential focused radiation field closely following the contour of the chest wall and lung periphery, potentially limiting toxicity to the lung parenchyma, allow postoperative radiation doses after $\mathrm{P} / \mathrm{D}$ to be nearly the same as after EPP: $45-50$ centigray. ${ }^{11-14}$

The role of preoperative radiation was evaluated in the Surgery for Mesothelioma After Radiation Therapy ("SMART") trial, which was a feasibility study only. ${ }^{15}$ Five fractions of radiation were given to the hemithorax 1 week prior to EPP, with no acute pulmonary toxicities noted in 26 patients but with half the patients developing postoperative complications. Although survival data was reported and an enhanced immune response speculated, more studies are needed before any conclusions can be made regarding impact.

\section{Multimodality therapy}

Currently, specialized mesothelioma centers employ multimodality approaches, including surgical resection, chemotherapy, and radiation, with survival in excess of 20 months depending on stage. ${ }^{5}$ Reports from the Society of Thoracic Surgeons Database ${ }^{16}$ and the European Organisation for Research and Treatment of Cancer strongly suggest that multimodality therapy in highly specialized centers is associated with less morbidity and mortality. ${ }^{17}$

\section{Hyperthermic intraoperative chemotherapy}

Experimental data suggests that heating chemotherapeutic agents increases entry into tumor cells. Clinically, most data come from Phase I-II studies evaluating systemic toxicity of intrapleural drug (most commonly cisplatin) administration in highly selected patients. ${ }^{18}$ Median survival of patients

Table I Studies evaluating toxicity of radiation in intact lung

\begin{tabular}{|c|c|c|c|c|c|}
\hline Study & $\mathbf{N}$ & Radiation dose & Pulmonary toxicity & $\begin{array}{l}\text { Median survival, } \\
\text { months }\end{array}$ & $\begin{array}{l}\text { Overall } \\
\text { survival }\end{array}$ \\
\hline \multirow[t]{3}{*}{ Minatel et al ${ }^{11,12}$} & $28^{a}$ & 5,000 cGy in 25 fractions & 17.8\%: & 33 & 2 years $-70 \%$ \\
\hline & & & Grade 2 in 3 patients & & 3 years $-49 \%$ \\
\hline & & & Grade 3 in 2 patients & & \\
\hline \multirow[t]{3}{*}{ Rosenzweig et $\mathrm{al}^{13}$} & $36^{\mathrm{b}}$ & 4,680 cGy (range & $20 \%:$ & 26 & I year - 75\%; \\
\hline & & $4, \mid$ 40-I45,040 cGy) & Grade 3 in 5 patients & & 2 years $-53 \%$ \\
\hline & & & Grade $4-5$ in 2 patients & & \\
\hline \multirow[t]{3}{*}{ Bolukbas et al ${ }^{14}$} & $29^{c}$ & 5,040 cGy & No report of radiation & 30 & I year $-69 \%$ \\
\hline & & & toxicity specifically; note & & 2 years $-50 \%$ \\
\hline & & & that it was well tolerated & & 3 years $-31 \%$ \\
\hline Cho et al ${ }^{15}$ & 25 & $\begin{array}{l}2,500 \text { cGy in } 5 \text { fractions + } \\
500 \text { cGy boost }\end{array}$ & $\begin{array}{l}\text { None at I week when } \\
\text { patients underwent EPP }\end{array}$ & NR & 3 years $-58 \%$ \\
\hline
\end{tabular}

Notes: aTwenty patients underwent pleurectomy/decortication and eight patients had biopsy only prior to radiation. Survival is reported for 20 patients who underwent pleurectomy/decortication and radiation. ${ }^{\mathrm{b} T}$ wenty patients underwent pleurectomy and decortication and 16 patients had no surgery prior to radiation. ${ }^{\mathrm{C}}$ Only five patients underwent 5,040 cGy of radiation; 29 additional patients received 2,100 cGy in three fractions to the incision and chest tube sites.

Abbreviations: cGy, centigray; EPP, extrapleural pneumonectomy; N, number of patients; NR, not reported. 
treated with this methodology ranges from 9-20 months and there may be a trend toward prolonged disease-free intervals in those treated with higher doses. ${ }^{19}$ A retrospective review by Sugarbaker et $\mathrm{al}^{20}$ reported a longer survival and progression free interval in early-stage patients treated with hyperthermic intraoperative chemotherapy. However, lack of randomized trials raises a question whether this method represents significant benefit.

\section{New and future therapies}

Successful treatment of mesothelioma will depend on improved understanding of the biology of mesothelioma. ${ }^{21}$ Clinicaltrials.gov listed 192 registered trials (Phases I-III) worldwide evaluating multiple therapeutic approaches in a variety of settings. A large number of these trials focus on novel agents, which have arisen primarily from our expanded knowledge of molecular signaling and immune response. Several classes of targeted therapies have emerged from preclinical work and are being evaluated. These focus on following broad mechanisms:

- Tyrosine kinase inhibitors

- Antibody conjugated toxins

- Immune checkpoint inhibitors

- Gene therapy

- Tumor vaccines.

\section{Tyrosine kinase inhibitors}

Epidermal growth factor receptor

Epidermal growth factor receptor (EGFR) is expressed by a variety of epithelial malignancies, and activation of the pathway interferes with apoptosis, uncontrolled cell proliferation, and agiogenesis. ${ }^{22}$ EGFR overexpression in mesothelioma samples was reported by several authors, ${ }^{23-25}$ and inhibition of EGFR-dependent signaling pathway in mesothelioma cell lines also leads to decreased cell survival. ${ }^{22}$
Several clinical trials based on these findings have been conducted but, disappointingly, did not show improved survival (summarized in Table 2). Furthermore, the level of EGFR overexpression did not correlate with clinical outcomes. ${ }^{26}$ Additional data showed that mutations found in patients with other cancers may not be the same in malignant mesothelioma tumors, ${ }^{25}$ or alternatively the frequency of mutation may be too low in mesothelioma patients, ${ }^{24}$ resulting in the lack of clinical response in nonselected patients.

\section{Vascular endothelial growth factor}

Vascular endothelial growth factor (VEGF) is produced by a variety of tumors, including pleural mesothelioma, and stimulates neovascularization of tumors ${ }^{30}$ in addition to normal angiogenesis. Elevated levels of VEGF and its receptor have been detected by immunohistochemistry in the tissue specimens of patients with mesothelioma ${ }^{31,32}$ and as free circulating molecules. ${ }^{33}$ Higher levels may be reflective of more-advanced disease and were associated with shorter survival in both studies. In vitro studies demonstrated that increased mesothelioma cell proliferation occurred when treated with VEGF and that significant inhibition of cell growth occurred when this pathway was blocked. ${ }^{34}$ As a result, interference with this pathway potentially could lead to successful therapy.

VEGF antibody binds the receptor and inhibits its activation. ${ }^{30}$ Bevacizumab has been approved to treat advanced colorectal, renal cell, and gastrointestinal stromal cancers. Numerous clinical trials (Table 3) evaluated the effect of VEGF inhibitors alone and in combination with chemotherapy in MPM. Unfortunately, the results of these trials have been disappointing. Overall survival ranged from 4-15 months and this difference was likely due to the highly variable design of individual trials. For instance, several trials required failure of first-line therapy

Table 2 Summary of published clinical trials evaluating blocking effects of EGFR

\begin{tabular}{|c|c|c|c|c|c|}
\hline Agent/author & Study design & $\mathbf{N}$ & $\begin{array}{l}\text { Median survival } \\
\text { (months) }\end{array}$ & $\begin{array}{l}\text { Overall I-year } \\
\text { survival }\end{array}$ & Response and comments \\
\hline Gefitinib & Phase II & 43 & $6.8^{\mathrm{a}}$ & $32 \%$ & I complete response; I partial response; \\
\hline Govindan et $\mathrm{al}^{27}$ & No prior systemic chemo & & & & $\begin{array}{l}\text { EGFR expression does not predict } \\
\text { response }\end{array}$ \\
\hline Erlotinib & Phase II & 63 & 10 & $43 \%$ & None had response; no correlation \\
\hline Garland et $\mathrm{al}^{28}$ & No prior systemic chemo & & & & between EGFR expression and response \\
\hline $\begin{array}{l}\text { Erlotinib and } \\
\text { bevacizumab }\end{array}$ & $\begin{array}{l}\text { Phase II } \\
\text { Prior systemic chemo }\end{array}$ & 24 & 5.8 & $24 \%$ & $\begin{array}{l}\text { No responses observed; } 12 \text { with stable } \\
\text { disease }\end{array}$ \\
\hline Jackman et $\mathrm{al}^{29}$ & & & & & \\
\hline
\end{tabular}

Note: ${ }^{\text {In }}$ this study, survival varied from 8.1 months in patients with high EGFR levels and 3.6 months in patients with low EGFR expression.

Abbreviations: EGFR, epidermal growth factor receptor; $\mathrm{N}$, number of patients. 


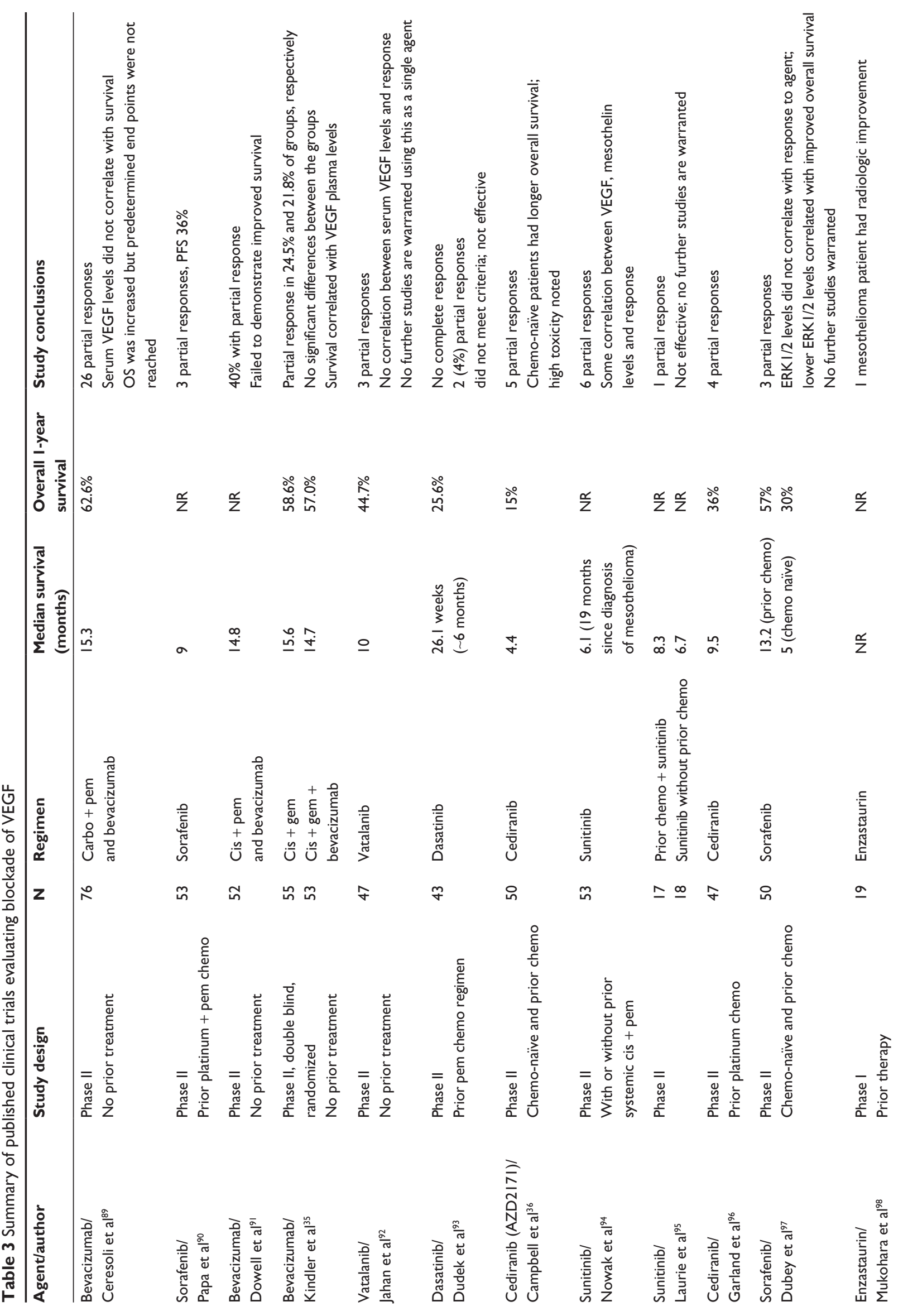




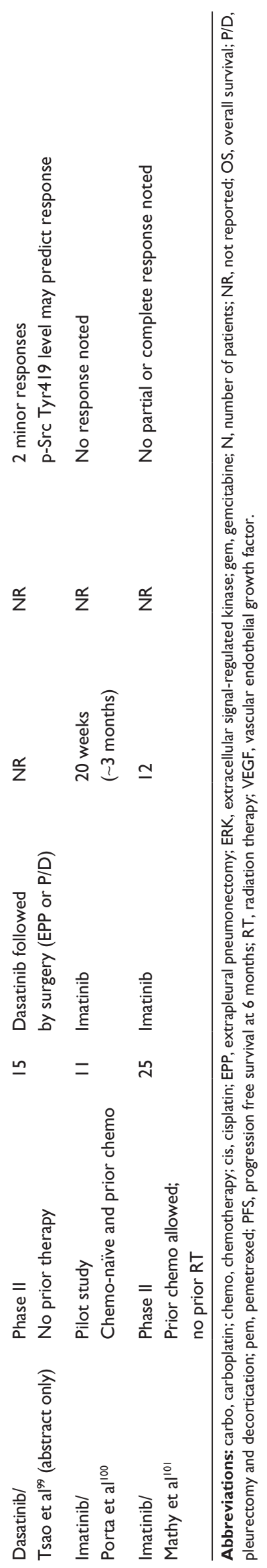

before initiation of VEGF antibody treatment, while other trials allowed it to be given as first-line therapy. The only study ${ }^{35}$ with a truly prospective randomized allocation to either standard chemotherapy (cisplatin and pemetrexed) or standard chemotherapy with addition of bevacizumab showed no difference in disease progression or overall survival.

Toxicities of TKIs were usually well tolerated, and only one trial concluded that it was excessive and the agent should not be used. ${ }^{36}$ Table 4 summarizes ongoing trials, but results have been uniformly disappointing and it is unclear whether these agents will assume significant clinical roles.

\section{Additional molecular targets}

In addition to a large number of kinase inhibitors, several other specific molecular agents are being investigated. Some of these agents influence a common pathway downstream of the EGFR pathway, while other exert action via different mechanisms. For example, histone deacetylase inhibitors (belinostat and vorinostat) exert their action through modification of histones, thus controlling gene transcription. ${ }^{37}$ A clinical trial evaluating belinostat in 13 patients was not promising, having found belinostat to be ineffective as a single second-line regimen in patients with MPM. ${ }^{38}$ As a result, a planned trial of vorinostat combined with chemotherapy has been halted.

Bortezomib is a selective inhibitor that acts via downregulation of nuclear factor- $\mathrm{\kappa B}$ and promotes apoptosis. Despite having favorable preclinical results, bortezomib was associated with significant toxicity and lack of expected response in early clinical trials. ${ }^{39}$ Additional investigational strategies evaluated the role of arginine depletion, effect of everolimus, role of HSP90 inhibitors, ranpirnase, and more. These active trials are summarized in Table 5.

\section{Therapy targeting cell-surface receptors Mesothelin}

Mesothelin is a $40 \mathrm{kDa}$ cell-surface differentiation glycosylphosphatidylinositol-anchored glycoprotein present on normal mesothelial cells and overexpressed on the surface of mesothelioma as well as ovarian and pancreatic adenocarcinoma cells. It is shed into pleural fluid and released into the serum in $71 \%$ of mesothelioma, $67 \%$ of ovarian, and nearly all pancreatic cancer patients, but also in normal volunteers. ${ }^{40,41}$ Mesothelin overexpression, occurring more prominently on epithelioid tumors, may serve to alter cell adhesion and/or invasion. ${ }^{42}$ 
Table 4 Summary of ongoing clinical trials evaluating various kinase inhibitors

\begin{tabular}{|c|c|c|c|c|}
\hline Therapy & Number of trials & Agent & Trial ID & Phase \\
\hline \multirow[t]{8}{*}{ VEGFR kinase inhibitors } & 8 & Bevacizumab & NCT0065I 456 & II \\
\hline & & Bevacizumab & NCT0060446I $\left.\right|^{a}$ & II \\
\hline & & Nintedanib & NCTOI907I00 & ॥ \\
\hline & & Dovitinib & NCT0I769547 & I-II \\
\hline & & Cediranib & NCT0I064648 & I-II \\
\hline & & Axitinib & NCTOI 211275 & I \\
\hline & & Dasatinib & NCT00652574 & I \\
\hline & & Imatinib & NCT00402766 & \\
\hline EGFR kinase inhibitor & I & Cetuximab & NCT00996567 & ॥ \\
\hline \multirow[t]{4}{*}{ Other kinase inhibitors } & 3 & PF-03446962 & NCT0I486368 & II \\
\hline & & (anti-ALK antibody) & & \\
\hline & & Defactinib (FAK) & NCT0I870609 & II \\
\hline & & Defactinib (FAK) & NCT02004028 & II \\
\hline
\end{tabular}

Note: ${ }^{2}$ Trial was terminated.

Abbreviations: ALK, activin receptor-like kinase; EGFR, epidermal growth factor receptor; ID, identification number;VEGFR, vascular endothelial growth factor receptor; FAK, focal adhesion kinase.

\section{Antimesothelin antibodies}

MORAb-009 (amatuximab) is a chimeric IgG1kappa murine monoclonal antibody with high affinity for human mesothelin. ${ }^{43}$ Following receptor binding, this highly specific antibody is rapidly internalized ${ }^{43}$ and induces antibody-dependent cellular cytotoxicity and inhibits cellular adhesions via interaction with MUC16 in a receptor density-dependent manner. ${ }^{44}$ Preclinical studies in nude mice suggested that MORAb-009 combined with chemotherapy (gemcitabine or paclitaxel) was more effective than either chemotherapy agent alone. ${ }^{43}$ An initial Phase I clinical trial demonstrated that MORab-009 is well tolerated, with a maximum tolerated dose of $200 \mathrm{mg} / \mathrm{m}^{2}$, and that eleven of 24 patients exhibited stable disease. ${ }^{45} \mathrm{~A}$ Phase II clinical trial (Clinicaltrials.gov NCT00738582) evaluating the combination of MORab-009 with cisplatin and pemetrexed in patients with pleural mesothelioma has completed recruitment but results have not been published.

BAY 94-9343 (anetuman ravtansine) is a fully human antimesothelin antibody coupled via a reducible disulfide linker to DM4, a microtubule-targeting toxophore that shows highly selective cytotoxicity against cells with high levels of mesothelin expression with an additional potent bystander effect. ${ }^{46}$ Preclinical studies showed a dose-dependent and receptor-dependent $94 \%$ reduction of tumor growth with BAY 94-9343 compared to $70 \%$ with cisplatin and pemetrexed chemotherapy ${ }^{46}$ This drug is now being evaluated in an ongoing Phase I trial (Clinicaltrials.gov NCT01439152).

\section{CRS-207 vaccine}

CRS-207 is a genetically modified Listeria monocytogenes attenuated vaccine expressing mesothelin. Mesothelin acts as an antigen and stimulates activation of T-cells upon exposure to CRS-207. ${ }^{47}$ A Phase I trial, including five mesothelioma patients, determined the maximum tolerated dose to be $1 \times 109$ colony-forming units with a favorable safety profile. ${ }^{47}$ Mesothelin-specific CD8+ T-cell response was induced in six out of ten evaluable subjects but did not correlate with clinical response. Currently, an ongoing Phase I trial (Clinicaltrials.gov NCT01675765) is evaluating Listeria vaccine in combination with chemotherapy in patients with MPM.

\section{SSIP immunotoxin}

SS1P is an immunotoxin consisting of an antimesothelin antibody variable fragment linked to a cytotoxic fragment of Pseudomonas exotoxin A. A Phase I trial including 16 patients with mesothelioma showed that SS1P was well tolerated up to $25 \mu \mathrm{g} / \mathrm{kg} / \mathrm{day} \times 10$ days with modest clinical activity and minor responses, and that two mesothelioma patients had symptomatic improvement. ${ }^{48}$ Continuous infusion showed no advantage over bolus dosing. ${ }^{49} \mathrm{~A}$ significant number of patients developed neutralizing antibodies after one cycle and were not able to receive additional therapy. In a subsequent study, Hassan et $\mathrm{al}^{50}$ attempted to abrogate the production of neutralizing antibodies by inducing an immunosuppressive state with pentostatin and cyclophosphamide. Interestingly, three of ten patients achieved a partial response, but two patients (one with stable and one with progressive disease) experienced dramatic tumor reduction with subsequent chemotherapy. Durable responses were correlated with high serum SS1P levels following the second dose and with multiple doses of therapy. The median overall survival was 8.8 months with a median follow-up of 12.7 months. ${ }^{50} \mathrm{~A}$ Phase I trial (Clinicaltrials.gov NCT01445392) of SS1P infusion 


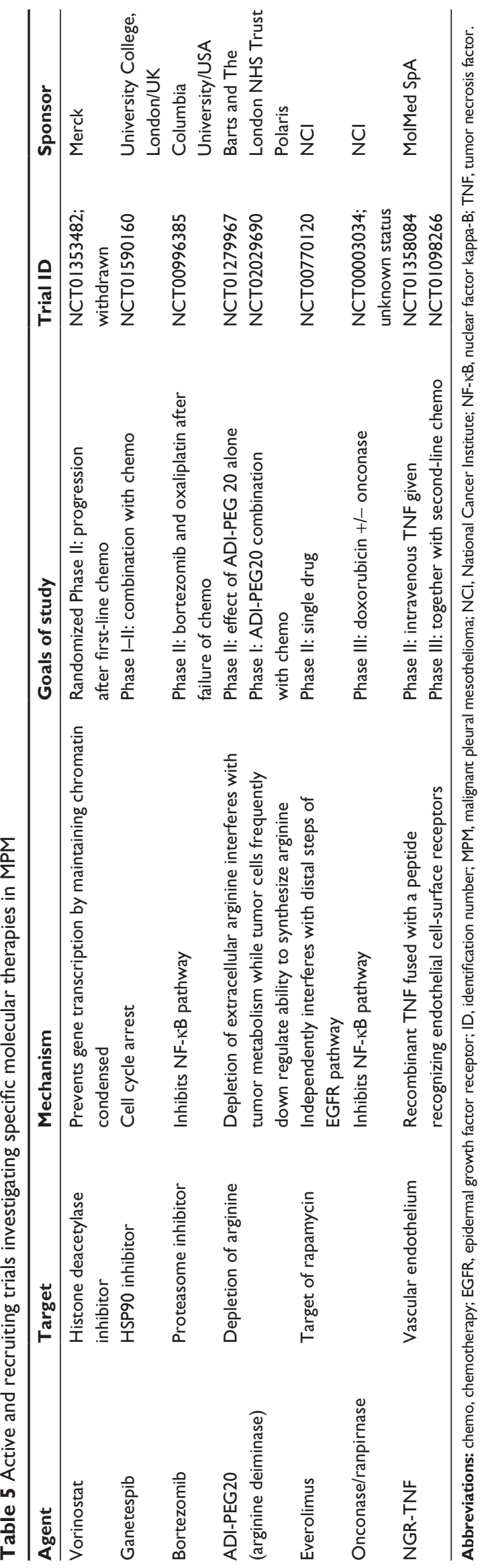

combined with chemotherapy (cisplatin and pemetrexed) is closed to recruitment and awaiting data analysis.

\section{Interleukin-4 receptor}

Interleukin-4 (IL-4) acts as a growth factor for T helper 2 cells and induces immunoglobulin class switch in allergic responses. Several studies showed that in addition to some subsets of immune cells, high affinity IL-4 receptors also are present on a variety of human tumors including mesothelioma..$^{51-53}$ Clinically, high levels of IL-4 receptor expression have been shown on fresh human mesothelioma specimens and correlated with a worse outcome. ${ }^{54,55}$ Furthermore, higher IL-4 receptor expression levels were noted in biphasic and sarcomatoid histology specimens, which have a significantly worse prognosis compared to epitheloid histology. ${ }^{55}$ These IL-4 receptors, therefore, represent potential clinical targets.

Beseth et a ${ }^{54}$ showed that a circularly permuted recombinant IL-4 toxin IL-4(38-37)-PE38KDEL or cpIL-4-PE that contains amino acids $38-129$ of IL-4 fused by a peptide linker to amino acids $1-37$, which are in turn fused to amino acids 353-364 and 381-608 of Pseudomonas exotoxin. KDEL at positions 609-612 allows it reversibly bind to mesothelioma cells and inhibit protein synthesis in vitro. In a human mesothelioma xenograph nude mouse model, intratumoral injection of IL-4(38-37)-PE38KDEL significantly reduced tumor volumes in a dose-dependent manner compared to the control and IL-4-treated mice. ${ }^{54}$ Furthermore, survival of similarly treated mice was significantly prolonged to a median of $>102$ days from 28 days in the two control groups $(P<0.0001)$. Yang et $\mathrm{al}^{56}$ reported similar findings with a hybrid IL-4R $\alpha$-lytic peptide designed by the group. Although a pancreatic model was used, the results could be applied to mesothelioma. Phase I trials are being planned but have not yet started to accrue patients.

\section{Immune checkpoint inhibitors Cytotoxic T lymphocyte antigen-4}

Immune checkpoints are pathways that dampen inflammatory responses and mediate immune tolerance toward normal tissue. Because most immune checkpoints are initiated by ligand-receptor interactions, they can be readily blocked by antagonist antibodies or recombinant forms of cognate ligands/receptors. Cytotoxic T lymphocyte antigen-4 (CTLA-4) is vital for maintaining host immune tolerance to established tumors. ${ }^{57}$ The CTLA-4 receptor sequesters CD80 and CD86 immune costimulatory signals provided by antigen-presenting cells, thus raising the activation threshold for T lymphocytes. Systemic administration of 
CTLA-4 blocking antibody as monotherapy or combined with therapeutic tumor-cell vaccination induced regression of established melanoma and colon tumors in mice. ${ }^{57,58}$

A Phase II trial evaluating anti-CTLA-4 antibody (tremelimumab) in 29 patients with chemotherapy-resistant advanced mesothelioma (28 pleural and 1 peritoneal) was recently reported by Calabrò et al. ${ }^{59}$ Objective clinical responses were observed in only two of 29 patients. However, disease stabilization was noted in nine patients (31\%), all with epithelioid histology. Overall survival rates were $48 \%$ at 1 year and $37 \%$ at 2 years. Currently, there are two active clinical trials investigating the administration of tremelimumab in patients with pleural mesothelioma (ClinicalTrials.gov NCT01655888 and NCT01843374).

\section{Programmed death receptor-I}

Programmed death receptor is found on the surface of T-cells and its stimulation leads to T-cell deactivation, thus allowing escape from the immune system surveillance in the presence of otherwise antigenic substrate. ${ }^{60}$ Activation of this receptor occurs by a programmed death ligand 1 (PD-L1), which exists within the tumor microenvironment on the surface of tumor cells. ${ }^{61}$

Currie et $\mathrm{al}^{60}$ demonstrated PD-L1 to be present on murine mesothelioma cells in vivo. Interestingly, upregulation of PD-L1 expression occurred in response to increased concentrations of interferon (IFN)- $\gamma$ and T-cells in tumor draining lymph nodes, supporting the hypothesis that this is an important pathway of tumor-mediated local immunosuppression. ${ }^{60}$ The effect of PD-L1 blockade on different subpopulations of T-cells produced opposing effects on tumor progression and suggested that tumor-derived immune suppression is mediated by specific subsets of T-cells. Mansfield et $\mathrm{al}^{62}$ noted that PD-L1 expression occurred in approximately $40 \%$ of 106 mesothelioma specimens (all sarcomatoid tumors) and higher expression was correlated with worse prognosis (5.0 months versus 14.5 months).
Several trials are currently evaluating role of inhibition in this pathway using different agents (lambrolizumab and nivolumab) in cancers other then MPM.

\section{Gene therapy}

Multiple genetic abnormalities have been identified in mesothelioma, and a variety of genetic manipulation strategies have been employed in preclinical studies. ${ }^{63}$ Several types of gene therapies have shown particular promise and are discussed below.

\section{Suicide gene therapy}

This approach utilizes engineered viruses that deliver transgenes encoding enzymes that metabolize prodrugs into toxic metabolites capable of killing tumor cells. Multiple viral vectors have been studied. A clinical trial of intrapleural Adenovirus herpes simplex thymidine kinase/ ganciclovir ${ }^{64}$ enrolled 34 patients and reported minimal morbidity and a dose-dependent median survival as high as 15 months at the highest viral titers. Some patients experienced prolonged survival, suggesting induction of antitumor immunity in addition to the acute viral-mediated cytotoxicity. ${ }^{64}$

\section{Cytokine gene therapy}

Another strategy involves administration of viral vectors encoding specific cytokine gene(s) that may exert a direct cytotoxic effect on tumor cells or may alter the immunologic response(s) to the tumor. Although early trials of direct intrapleural administration of interleukin-2 (IL-2) showed a nearly $50 \%$ response rate and a 28 -month median survival in responders, ${ }^{65}$ subsequent interest has centered on gene therapy with IFN, which play a key role in activation of the immune system and have direct antitumor cytotoxic/cytostatic effects. Several clinical trials (summarized in Table 6) evaluated

Table 6 Clinical trials involving gene therapy in treatment of MPM

\begin{tabular}{|c|c|c|c|c|}
\hline Study & Type of therapy & $\mathbf{N}$ & Survival, months & Comments \\
\hline Sterman & Intrapleural adenovirus & 34: & $M S-15$ & Neutralizing antibody developed \\
\hline et $\mathrm{al}^{64}$ & Herpes simplex suicide gene & $\begin{array}{l}21 \text { high dose } \\
13 \text { low dose }\end{array}$ & $M S-10$ & $\begin{array}{l}\text { Suggests that response may be due to } \\
\text { immunologic stimulation by tumor antigens }\end{array}$ \\
\hline $\begin{array}{l}\text { Sterman } \\
\text { et } \mathrm{al}^{66}\end{array}$ & $\begin{array}{l}\text { Intrapleural adenoviral vector } \\
\text { with IFN } \beta \text { gene } \times \text { I dose }\end{array}$ & 8 & $\begin{array}{l}\text { NR } \\
(3 \text { patients alive) }\end{array}$ & $\begin{array}{l}\text { Activation of NK cells and increase in levels } \\
\text { of anti-mesothelin antibody in some patients }\end{array}$ \\
\hline $\begin{array}{l}\text { Sterman } \\
\text { et } \mathrm{al}^{67}\end{array}$ & $\begin{array}{l}\text { Intrapleural adenoviral vector } \\
\text { with IFN } \beta \text { gene } \times 2 \text { doses }\end{array}$ & 10 & OS $>18$ months $^{\mathrm{a}}$ & $\begin{array}{l}\text { Neutralizing antibody production noted } \\
\text { with lower subsequent pleural IFN levels }\end{array}$ \\
\hline $\begin{array}{l}\text { Sterman } \\
\text { et } \mathrm{al}^{68}\end{array}$ & $\begin{array}{l}\text { Intrapleural adenoviral vector } \\
\text { with IFN } \alpha 2 b \text { gene } \times 2 \text { doses }\end{array}$ & 9 & $\begin{array}{l}\text { NR } \\
\text { (OS ranged from I-22 } \\
\text { months with } 3 \text { patients alive) }\end{array}$ & Strong activation of NK cells \\
\hline
\end{tabular}

Note: Includes seven additional patients with malignant effusions from ovarian, breast, or lung carcinomas.

Abbreviations: IFN, interferon; MPM, malignant pleural mesothelioma; MS, median survival; N, number of patients; NK, natural killer; NR, not reported; OS, overall survival. 
Table 7 Current investigations in gene therapy

\begin{tabular}{|c|c|c|c|c|c|}
\hline Gene therapies & Agent & $\begin{array}{l}\text { Route of } \\
\text { administration }\end{array}$ & Status & Study ID & Sponsor \\
\hline \multirow[t]{2}{*}{ Cytokine-based } & Interferon & Intrapleural & Recruiting & NCTOI2I 2367 & University of Pennsylvania/ NCl \\
\hline & Interferon with chemotherapy & Intrapleural & Unknown & NCTOIII9664 & University of Pennsylvania \\
\hline \multirow[t]{2}{*}{ Suicide gene } & Herpes simplex virus & Intrapleural & Recruiting & NCT0I7210I8 & Virttu Biologics Limited \\
\hline & Measles virus & Intrapleural & Recruiting & NCT0I503I77 & Mayo Clinic/NCl \\
\hline Autologous modified & Fibroblast activation protein & Intrapleural & Not yet recruiting & NCT0I722I49 & University of Zurich \\
\hline T-cells with receptor to: & Mesothelin & Intravenous & Recruiting & NCTOI 355965 & University of Pennsylvania \\
\hline
\end{tabular}

Abbreviations: ID, identification number; $\mathrm{NCl}$, National Cancer Institute.

adenoviral-mediated IFN ( $\alpha$ and $\beta$ ) therapy in patients with MPM. ${ }^{66-68}$ Survival ranged from 1-22 months with some longterm survival, but neutralizing antibodies did limit ability to administer repeated treatments.

\section{Gene-modified lymphocytes}

Genetically engineered autologous $\mathrm{T}$ lymphocytes may increase antigen recognition or alter the immunosuppressive tumor microenvironment through production of cytokines. ${ }^{69}$ Carpenito et $\mathrm{al}^{70}$ reported that antimesothelin-engineered T-cells mediated specific cytolysis of mesothelin-expressing cells and produced significant tumor regression in animals. Fibroblast activating protein ${ }^{71}$ and chemokine receptor- $2^{72}$ also have been evaluated in vitro as possible additional candidates for T-cell genetic modifications.

Currently ongoing clinical trials involving gene therapies are summarized in Table 7.

\section{Immunotherapy and vaccines Dendritic cell vaccines}

Successful cancer immunotherapy requires effective antigen presentation. Antigen-exposed autologous dendritic cells remain the most potent antigen presenting cell. Preclinical in vitro and in vivo data supports the use of dendritic cell vaccines as a valuable strategy in mesothelioma. ${ }^{73}$ Calretinin, mesothelin, and Wilm's tumor-1 have been used as candidate antigens, and measurable specific immune responses were shown to these antigens in early clinical trials, although no responses were seen. ${ }^{74,75}$ In a pilot Phase I study, Hegmans et al ${ }^{76}$ exposed autologous dendritic cells ex vivo to autologous tumor antigens purified from pleural effusions or biopsy samples. This vaccine strategy was well tolerated and produced three partial responses with overall median survival of 19 months, which is encouraging.

Currently, several manufactured mesothelioma vaccines are being evaluated in Phase I-II clinical trials and are summarized in Table 8.

\section{Direct physical cytotoxic therapies} Photodynamic therapy

Photodynamic therapy (PDT) was originally investigated by Pass at the National Cancer Institute in the $1980 \mathrm{~s}^{77} \mathrm{PDT}$ recently has been used by Friedberg et $\mathrm{al}^{78}$ following a meticulous P/D. In a Phase I-II experience, the median disease-free progression was 15 months and the overall survival was over 40 months. $^{78}$ Due to this encouraging data, a Phase II trial (NCT NCT02153229) is ongoing and a randomized Phase III trial now is being planned, as is further investigation into the basic science of PDT (NCT02106559).

Table 8 Active trials investigating vaccine-based strategy

\begin{tabular}{|c|c|c|c|}
\hline Vaccine antigen & $\begin{array}{l}\text { Additional therapies combined } \\
\text { with vaccine }\end{array}$ & Trial ID & Sponsor \\
\hline WT-I (randomized) & GM-CSF & NCTOI 265433 & Memorial Sloan-Kettering Cancer Center \\
\hline WT-I & GM-CSF & NCT0I890980 & MD Anderson Cancer Center \\
\hline $\begin{array}{l}5 \text { T } 4 \text { tumor-associated antigen expressed } \\
\text { by modified vaccinia virus (TroVax) }\end{array}$ & Chemotherapy & NCTOI569919 & Wales Cancer Trials \\
\hline $\begin{array}{l}\text { PA-I-STK compound } \\
\text { - modified ovarian carcinoma vaccine }\end{array}$ & Cancyclovir & NCT000062I6 & University of Louisiana, $\mathrm{NCl}$ \\
\hline Allogeneic tumor cell ${ }^{\mathrm{a}}$ & Cyclophosphamide and celecoxib & NCT 01143545 & $\mathrm{NCl}$ \\
\hline Mesothelin (CRS-207) & Chemotherapy & NCT0I 675765 & Aduro BioTech Inc \\
\hline
\end{tabular}

Note: ancludes malignant mesothelioma, lung, esophageal, and thymic cancers.

Abbreviations: GM-CSF, granulocyte/macrophage colony-stimulating factor; ID, identification number; NCI, National Cancer Institute; WT-I, Wilm's tumor-I. 


\section{Heated therapy}

Sugarbaker ${ }^{18-20}$ has advocated in favor of intraoperative hyperthermic chemotherapy; however, evidence supporting the use of hyperthermia is quite limited. No controlled trials exist and a recent report by Cameron and $\mathrm{Hou}^{79}$ suggested that temperatures required for a clinically meaningful effect were $43^{\circ} \mathrm{C}-45^{\circ} \mathrm{C}$, far above those currently used at most centers, and that hyperthermia and chemotherapy were additive and not synergistic.

\section{lodine-povidone (betadine) lavage}

A Phase I-II trial of intraoperative hyperthermic $\left(41^{\circ} \mathrm{C}\right)$ iodine-povidone lavage following surgery (either P/D or EPP) was recently reported by Lang-Lazdunski et al. ${ }^{80}$ Mechanism of action is likely generation of reactive oxygen intermediate species leading to cellular necrosis ${ }^{81}$ Although the treatment was tolerated well and the surgical outcomes were acceptable, convincing evidence of efficacy is still lacking.

\section{Cryotherapy}

Cryotherapy for the treatment of cancer has been used for decades. ${ }^{82-85}$ Abtin et al ${ }^{86}$ recently reported the use of percutaneous cryoablation in 24 mesothelioma patients for control of limited recurrent local disease following P/D. The treatment was well tolerated, had a $>90 \%$ control rate, and was associated with a median survival of 11.4 months following first therapy (36.1 months following surgery). Cryotherapy also may enhance immune responses through enhanced natural killer cell activity, T-cell responses and systemic IFN production. ${ }^{87}$ In an animal model of prostate cancer, tumor cryotherapy with simultaneous anti-CTLA-4 immunotherapy produced enhanced immune-mediated protection against tumor rechallenge at both primary and distant tumor sites. ${ }^{88}$

\section{Summary}

MPM remains a challenging tumor to control. Despite some benefit from surgery and combination chemotherapy (cisplatin/pemetrexed), survival remains poor. ${ }^{6}$ However, the list of potential new therapies is long and the number of clinical trials is impressive (nearly 200). With all the ongoing research, progress is only a matter of time. Although the low prevalence of this disease makes enrollment in clinical trials challenging, more than 1,000 patients over the last decade have participated in the clinical trials covered by this review. In the future, it is critical that clinicians treat this disease with equipoise and that patients be placed in randomized prospective clinical trials in order to truly determine optimal therapy for these patients.

\section{Disclosure}

The authors report no conflicts of interest in this work.

\section{References}

1. Seer.cancer.gov [database on the Internet]. Age adjusted incidence of mesothelioma all ages (SEER-13). Bethesda, MD: Surveillance, Epidemiology, and End Results Program. Available from: http:// seer.cancer.gov/faststats/selections.php?\#Output. Accessed July 5, 2014.

2. Delgermaa V, Takahashi K, Park EK, Le GV, Hara T, Sorahan T. Global mesothelioma deaths reported to the World Health Organization between 1994 and 2008. Bull World Health Organ. 2011;89(10):716-24, 724A.

3. Robinson BM. Malignant pleural mesothelioma: an epidemiological perspective. Ann Cardiothorac Surg. 2012;1(4):491-496.

4. Herndon JE, Green MR, Chahinian AP, Corson JM, Suzuki Y, Vogelzang NJ. Factors predictive of survival among 337 patients with mesothelioma treated between 1984 and 1994 by the Cancer and Leukemia Group B. Chest. 1998;113(3):723-731.

5. Flores RM, Zakowsky M, Venkatraman E, et al. Prognostic factors in the treatment of malignant pleural mesothelioma at a large tertiary referral center. J Thorac Oncol. 2007;2(10):957-965.

6. Vogelzang NJ, Rusthoven JJ, Symanowski J, et al. Phase III study of pemetrexed in combination with cisplatin versus cisplatin alone in patients with malignant pleural mesothelioma. J Clin Oncol. 2003;21(14):2636-2644.

7. Treasure T, Lang-Lazdunski L, Waller D, et al; MARS trialists. Extrapleural pneumonectomy versus no extra-pleural pneumonectomy for patients with malignant pleural mesothelioma: clinical outcomes of the Mesothelioma and Radical Surgery (MARS) randomised feasibility study. Lancet Oncol. 2011;12(8):763-772.

8. Lang-Lazdunski L, Bille A, Lal R, et al. Pleurectomy/decortication is superior to extrapleural pneumonectomy in the multimodality management of patients with malignant pleural mesothelioma. JThorac Oncol. 2012;7(4):737-743.

9. Scorsetti M, Bignardi M, Clivio A, et al. Volumetric modulation arc radiotherapy compared with static gantry intensity-modulated radiotherapy for malignant pleural mesothelioma tumor: a feasibility study. Int J Radiat Oncol Biol Phys. 2010;77(3):942-949.

10. Krayenbuehl J, Dimmerling P, Ciernik IF, Riesterer O. Clinical outcome of postoperative highly conformal versus 3D conformal radiotherapy in patients with malignant pleural mesothelioma. Radiat Oncol. 2014;9:32.

11. Minatel E, Trovo, M, Polesel J, et al. Tomotherapy after pleurectomy/ decortication or biopsy for malignant pleural mesothelioma allows the delivery of high dose of radiation in patients with intact lung. J Thorac Oncol. 2012;7(12):1862-1866.

12. Minatel E, Trovo M, Polesel J, et al. Radical pleurectomy/decortication followed by high dose of radiation therapy for malignant pleural mesothelioma. Final results with long-term follow up. Lung Cancer. 2014;83(1):78-82.

13. Rosenzweig KE, Zauderer MG, Laser B, et al. Pleural intensity-modulated radiotherapy for malignant pleural mesothelioma. Int $J$ Radiat Oncol Biol Phys. 2012;83(4):1278-1283.

14. Bölükbas S, Manegold C, Eberlein M, Bergmann T, Fisseler-Eckhoff A, Schirren J. Survival after trimodality therapy for malignant pleural mesothelioma: radical pleurectomy, chemotherapy and cisplatin/pemetrexed and radiotherapy. Lung Cancer. 2011;71(1):75-81.

15. Cho BC, Feld R, Leighl N, et al. A feasibiliy study evaluating surgery for mesothelioma after radiation therapy: the "SMART" approach for resectable malignant pleural mesothelioma. J Thorac Oncol. 2014;9(3):397-402. 
16. Burt BM, Cameron RB, Mollberg NM, et al. Malignant pleural mesothelioma and the Society of Thoracic Surgeons Database: an analysis of surgical morbidity and mortality. J Thorac Cardiovasc Surg. 2014;148(1):30-35.

17. Van Schil PE, Baas P, Gaafar R, et al; European Organisation for Research and Treatment of Cancer (EORTC) Lung Cancer Group. Trimodality therapy for malignant pleural mesothelioma: results from an EORTC phase II multicentre trial. Eur Respir J. 2010;36(6):1362-1369.

18. Mujoomdar AA, Sugarbaker DJ. Hyperthermic chemoperfusion for the treatment of malignant pleural mesothelioma. Semin Thorac Cardiovasc Surg. 2008;20(4):298-304.

19. Richards WG, Zellos L, Bueno R, et al. Phase I to II study of pleurectomy/decortication and intraoperative intracavitary hyperthermic cisplatin lavage for mesothelioma. J Clin Oncol. 2006;24(10):1561-1567.

20. Sugarbaker DJ, Gill RR, Yeap BY, et al. Hyperthermic intraoperative pleural cisplatin chemotherapy extends interval to recurrence and survival among low-risk patients with malignant pleural mesothelioma undergoing surgical macroscopic complete resection. J Thorac Cardiovasc Surg. 2013;145(4):955-963.

21. Gomez DR, Hong DS, Allen PK, et al. Patterns of failure, toxicity, and survival after extrapleural pneumonectomy and hemithoracic intensitymodulated radiation therapy for malignant pleural mesothelioma. J Thorac Oncol. 2013;8(2):238-245.

22. Jänne PA, Taffaro ML, Salgia R, Johnson BE. Inhibition of epidermal growth factor receptor signaling in malignant pleural mesothelioma. Cancer Res. 2002;62(18):5242-5247.

23. Okuda K, Sasaki H, Kawano O, et al. Epidermal growth factor receptor gene mutation, amplification and protein expression in malignant pleural mesothelioma. J Cancer Res Clin Oncol. 2008;134(10):1105-1111.

24. Cortese JF, Gowda AL, Wali A, Eliason JF, Pass HI, Everson RB. Common EGFR mutations conferring sensitivity to gefitinib in lung adenocarcinoma are not prevalent in human malignant mesothelioma. Int J Cancer. 2006;118(2):521-522.

25. Mezzapelle R, Miglio U, Rena O, et al. Mutation analysis of the EGFR gene and downstream signalling pathway in histologic samples of malignant pleural mesothelioma. $\mathrm{Br} J$ Cancer. 2013;108(8):1743-1749.

26. Destro A, Ceresoli GL, Falleni M, et al. EGFR overexpression in malignant pleural mesothelioma. An immunohistochemical and molecular study with clinico-pathological correlations. Lung Cancer. 2006;51(2):207-215.

27. Govindan R, Kratzke RA, Herndon JE, et al; Cancer and Leukemia Group B (CALGB 30101). Gefitinib in patients with malignant mesothelioma: a phase II study by the Cancer and Leukemia Group B. Clin Cancer Res. 2005;11(6):2300-2304.

28. Garland LL, Rankin C, Gandara DR, et al. Phase II study of erlotinib in patients with malignant pleural mesothelioma: a Southwest Oncology Group Study. J Clin Oncol. 2007;25(17):2406-2413.

29. Jackman DM, Kindler HL, Yeap BY, et al. Erlotinib plus bevacizumab in previously treated patients with malignant pleural mesothelioma. Cancer. 2008;113(4):808-814.

30. Takahashi S. Vascular endothelial growth factor (VEGF), VEGF receptors and their inhibitors for angiangiogenic tumor therapy. Biol Pharm Bull. 2011;34(12):1785-1788.

31. Demirag F, Unsal E, Yilmaz A, Caglar A. Prognostic significance of vascular endothelial growth factor, tumor necrosis, and mitotic activity index in malignant pleural mesothelioma. Chest. 2005;128(5):3382-3387.

32. Ohta Y, Shridhar V, Bright RK, et al. VEGF and VEGF type C play an important role in angiogenesis and lymphangiogenesis in human malignant mesothelioma tumours. Br J Cancer. 1999;81(1):54-61.

33. Yasumitsu A, Tabata C, Tabata R, et al. Clinical significance of serum vascular endothelial growth factor in malignant pleural mesothelioma. J Thorac Oncol. 2010;5(4):479-483.

34. Masood R, Kundra A, Zhu S, et al. Malignant mesothelioma growth inhibition by agents that target the VEGF and VEGF-C autocrine loops. Int J Cancer. 2003;104(5):603-610.
35. Kindler HL, Karrison TG, Gandara DR, et al. Multicenter, double-blind, placebo-controlled, randomized phase II trial of gemcitabine/cisplatin plus bevacizumab or placebo in patients with malignant mesothelioma. J Clin Oncol. 2012;30(20):2509-2515.

36. Campbell NP, Kunnavakkam R, Leighl N, et al. Cediranib in patients with malignant mesothelioma: a phase II trial of the University of Chicago Phase II Consortium. Lung Cancer. 2012;78(1):76-80.

37. Paik PK, Krug LM. Histone deacetylase inhibitors in malignant pleural mesothelioma: preclinical rationale and clinical trials. JThorac Oncol. 2010;5(2):275-279.

38. Ramalingam SS, Belani CP, Ruel C, et al. Phase II study of belinostat (PXD101), a histone deacetylase inhibitor, for second line therapy of advanced malignant pleural mesothelioma. J Thorac Oncol. 2009; 4(1):97-101.

39. Fennell DA, McDowell C, Busacca S, et al. Phase II clinical trial of first or second-line treatment with bortezomib in patients with malignant pleural mesothelioma. J Thorac Oncol. 2012;7(9):1466-1470.

40. Hassan R, Remaley AT, Sampson ML, et al. Detection and quantitation of serum mesothelin, a tumor marker for patients with mesothelioma and ovarian cancer. Clin Cancer Res. 2006;12(2):447-453.

41. Creaney J, Sneddon S, Dick IM, et al. Comparison of the diagnostic accuracy of the MSLN gene products, mesothelin and megakaryocyte potentiating factor, as biomarkers for mesothelioma in pleural effusions and serum. Dis Markers. 2013;35(2):119-127.

42. Servais EL, Colovos C, Rodriguez L, et al. Mesothelin overexpression promotes mesothelioma cell invasion and MMP-9 secretion in an orthotopic mouse model and in epithelioid pleural mesothelioma patients. Clin Cancer Res. 2012;18(9):2478-2489.

43. Hassan R, Ebel W, Routhier EL, et al. Preclinical evaluation of MORAb-009, a chimeric antibody targeting tumor-associated mesothelin. Cancer Immun. 2007;7:20.

44. Gubbels JA, Belisle J, Onda M, et al. Mesothelin-MUC16 binding is a high affinity, $\mathrm{N}$-glycan dependent interaction that facilitates peritoneal metastasis of ovarian tumors. Mol Cancer. 2006;5(1):50.

45. Hassan R, Cohen SJ, Phillips M, et al. Phase I clinical trial of the chimeric anti-mesothelin monoclonal antibody MORAb-009 in patients with mesothelin-expressing cancers. Clin Cancer Res. 2010;16(24): 6132-6138.

46. Golfier S, Kopitz C, Kahnert A, et al. Anetumab ravtansine: a novel mesothelin-targeting antibody-drug conjugate cures tumors with heterogeneous target expression favored by bystander effect. Mol Cancer Ther. 2014;13(6):1537-1548.

47. Le DT, Brockstedt DG, Nir-Paz R, et al. A live-attenuated Listeria vaccine (ANZ-100) and a live-attenuated Listeria vaccine expressing mesothelin (CRS-207) for advanced cancers: phase I studies of safety and immune induction. Clin Cancer Res. 2012;18(3):858-868.

48. Kreitman RJ. Hassan R, Fitzgerald DJ, Pastan I. Phase I trial of continuous infusion anti-mesothelin recombinant immunotoxin SS1P. Clin Cancer Res. 2009;15(16):5274-5279.

49. Hassan R, Bullock S, Premkumar A, et al. Phase I study of SS1P, a recombinant anti-mesothelin immunotoxin given as a bolus IV infusion to patients with mesothelin-expressing mesothelioma, ovarian, and pancreatic cancers. Clin Cancer Res. 2007;13(17):5144-5149.

50. Hassan R, Miller AC, Sharon E, et al. Major cancer regressions in mesothelioma after treatment with an anti-mesothelin immunotoxin and immune suppression. Sci Transl Med. 2013;5(208):208ra147.

51. Kawakami M, Kawakami K, Stepensky VA, et al. Interleukin 4 receptor on human lung cancer: a molecular target for cytotoxin therapy. Clin Cancer Res. 2002;8(11):3503-3511.

52. Obiri NI, Hillman GG, Haas GP, Sud S, Puri RK. Expression of high affinity interleukin-4 receptors on human renal cell carcinoma cells and inhibition of tumor cell growth in vitro by interleukin-4. J Clin Invest. 1993;91(1):88-93.

53. Obiri NI, Siegel JP, Varricchio F, Puri RK. Expression of high-affinity IL-4 receptors on human melanoma, ovarian and breast carcinoma cells. Clin Exp Immunol. 1994;95(1):148-155.

54. Beseth BD, Cameron RB, Leland P, et al. Interleukin-4 receptor cytotoxin as therapy for human malignant pleural mesothelioma xenografts. Ann Thorac Surg. 2004;78(2):436-443; discussion 436-443. 
55. Burt BM, Bader A, Winter D, Rodig SJ, Bueno R, Sugarbaker DJ. Expression of interleukin-4 receptor alpha in human pleural mesothelioma is associated with poor survival and promotion of tumor inflammation. Clin Cancer Res. 2012;18(6):1568-1577.

56. Yang L, Horibe T, Kohno M, et al. Targeting interleukin-4 receptor $\alpha$ with hybrid peptide for effective cancer therapy. Mol Cancer Ther. 2012;11(1):235-243.

57. Leach DR, Krummel MF, Allison JP. Enhancement of antitumor immunity by CTLA-4 blockade. Science. 1996;271(5256):1734-1736.

58. van Elsas A, Hurwitz AA, Allison JP. Combination immunotherapy of B16 melanoma using anti-cytotoxic T lymphocyte-associated antigen 4 (CTLA-4) and granulocyte/macrophage colony-stimulating factor (GM-CSF)-producing vaccines induces rejection of subcutaneous and metastatic tumors accompanied by autoimmune depigmentation. J Exp Med. 1999;190(3):355-366.

59. Calabrò L, Morra A, Fonsatti E, et al. Tremelimumab for patients with chemotherapy-resistant advanced malignant mesothelioma: an open-label, single-arm, phase 2 trial. Lancet Oncol. 2013;14(11):1104-1111.

60. Currie AJ, Prosser A, McDonnell A, et al. Dual control of antitumor CD8 $T$ cells through the programmed death-1/programmed deathligand 1 pathway and immunosuppressive $\mathrm{CD} 4 \mathrm{~T}$ cells: regulation and counterregulation. J Immunol. 2009;183(12):7898-7908.

61. Zou W, Chen L. Inhibitory B7-family molecules in the tumour microenvironment. Nat Rev Immunol. 2008;8(6):467-477.

62. Mansfield AS, Peikert T, Roden A, et al. Programmed cell death 1 ligand 1 expression and association with survival in mesothelioma. European Lung Cancer Conference 2014; 2014 Mar 26-29; Geneva, Switzerland. J Thorac Oncol. 2014;9(Supplement 9):S7-S52. Abstract \#1270.

63. Tagawa M, Tada Y, Shimada H, Hiroshima K. Gene therapy for malignant mesothelioma: current prospects and challenges. Cancer Gene Ther. 2013;20(3):150-156.

64. Sterman DH, Recio A, Vachani A, et al. Long-term follow-up of patients with malignant pleural mesothelioma receiving high-dose adenovirus herpes simplex thymidine kinase/ganciclovir suicide gene therapy. Clin Cancer Res. 2005;11(20):7444-7453.

65. Astoul P, Picat-Joossen D, Viallat JR, Boutin C. Intrapleural administration of interleukin-2 for the treatment of patients with malignant pleural mesothelioma: a Phase II study. Cancer. 1998;83(10):2099-2104.

66. Sterman DH, Recio A, Carroll RG, et al. A phase I clinical trial of single-dose intrapleural IFN-beta gene transfer for malignant pleural mesothelioma and metastatic pleural effusions: high rate of antitumor immune responses. Clin Cancer Res. 2007;13(15 Pt 1):4456-4466.

67. Sterman DH, Recio A, Haas AR, et al. A phase I trial of repeated intrapleural adenoviral-mediated interferon-beta gene transfer for mesothelioma and metastatic pleural effusions. Mol Ther. 2010;18(4):852-860.

68. Sterman DH, Haas A, Moon E, et al. A trial of intrapleural adenoviral-mediated interferon- $\alpha 2 \mathrm{~b}$ gene transfer for malignant pleural mesothelioma. Am J Respir Crit Care Med. 2011;184(12):1395-1399.

69. Wong RM, Ianculescu I, Sharma S, et al. Immunotherapy for malignant pleural mesothelioma. Current status and future prospects. Am J Respir Cell Mol Biol. 2014;50(5):870-875.

70. Carpenito C, Milone MC, Hassan R, et al. Control of large, established tumor xenografts with genetically retargeted human $\mathrm{T}$ cells containing CD28 and CD137 domains. Proc Natl Acad Sci U S A. 2009;106(9):3360-3365.

71. Schuberth PC, Hagedorn C, Jensen SM, et al. Treatment of malignant pleural mesothelioma by fibroblast activation protein-specific redirected T cells. J Transl Med. 2013;11:187.

72. Moon EK, Carpenito C, Sun J, et al. Expression of a functional CCR2 receptor enhances tumor localization and tumor eradication by retargeted human $T$ cells expressing a mesothelin-specific chimeric antibody receptor. Clin Cancer Res. 2011;17(14):4719-4730.

73. Hegmans JP, Hemmes A, Aerts JG, Hoogsteden HC, Lambrecht BN. Immunotherapy of murine malignant mesothelioma using tumor lysate-pulsed dendritic cells. Am J Respir Crit Care Med. 2005;171(10):1168-1177.
74. Powell A, Creaney J, Broomfield S, Van Bruggen I, Robinson B. Recombinant GM-CSF plus autologous tumor cells as a vaccine for patients with mesothelioma. Lung Cancer. 2006;52(2):189-197.

75. Krug LM, Dao T, Brown AB, et al. WT1 peptide vaccinations induce CD4 and CD8 T cell immune responses in patients with mesothelioma and non-small cell lung cancer. Cancer Immunol Immunother. 2010;59(10):1467-1479.

76. Hegmans JP, Veltman JD, Lambers ME, et al. Consolidative dendritic cell-based immunotherapy elicits cytotoxicity against malignant mesothelioma. Am J Respir Crit Care Med. 2010;181(12): 1383-1390.

77. Pass HI, DeLaney TF, Tochner Z, et al. Intrapleural photodynamic therapy: results of a phase I trial. Ann Surg Oncol. 1994;1(1):28-37.

78. Friedberg JS, Culligan MJ, Mick R, et al. Radical pleurectomy and intraoperative photodynamic therapy for malignant pleural mesothelioma. Ann Thorac Surg. 2012;93(5):1658-1665; discussion 1665-1667.

79. Cameron RB, Hou D. Intraoperative hyperthermic chemotherapy perfusion for malignant pleural mesothelioma: an in vitro evaluation. J Thorac Cardiovasc Surg. 2013;145(2):496-504.

80. Lang-Lazdunski L, Bille A, Belcher E, et al. Pleurectomy/decortication, hyperthermic pleural lavage with povidone-iodine followed by adjuvant chemotherapy in patients with malignant pleural mesothelioma. J Thorac Oncol. 2011;6(10):1746-1752.

81. Opitz I, Sigrist B, Hillinger S, et al. Taurolidine and povidone-iodine induce different types of cell death in malignant pleural mesothelioma. Lung Cancer. 2007;56(3):327-336.

82. Davol PE, Fulmer BR, Rukstalis DB. Long-term results of cryoablation for renal cancer and complex renal masses. Urology. 2006; 68(Suppl 1):2-6.

83. Sabel MS, Kaufman CS, Whitworth P, et al. Cryoablation of early-stage breast cancer: work-in-progress report of a multi-institutional trial. Ann Surg Oncol. 2004;11(5):542-549.

84. Zemlyak A, Moore WH, Bilfinger TV. Comparison of survival after sublobar resections and ablative therapies for stage I non-small cell lung cancer. J Am Coll Surg. 2010;211(1):68-72.

85. Chiang CL, Hagemann AR, Leskowitz R, et al. Day-4 myeloid dendritic cells pulsed with whole tumor lysate are highly immunogenic and elicit potent anti-tumor responses. PLoS One. 2011;6(12):e28732.

86. Abtin F, Suh R, Sandberg J, Rorie A, Cameron RB. Role of percutaneous cryoablation in management of recurrent mesothelioma following lung sparing pleurectomy and decortications. 2013 Society of Interventional Radiology 38th Annual Scientific Meeting; April 13-18, 2013; New Orleans, LA. J Vasc Interv Radiol. 2013;24(4):S139. Abstract \#319.

87. Sabel MS, Nehs MA, Su G, Lowler KP, Ferrara JL, Chang AE. Immunologic response to cryoablation of breast cancer. Breast Cancer Res Treat. 2005;90(1):97-104.

88. Waitz R, Solomon SB, Petre EN, et al. Potent induction of tumor immunity by combining tumor cryoablation with anti-CTLA-4 therapy. Cancer Res. 2012;72(2):430-439.

89. Ceresoli GL, Zucali PA, Mencoboni M, et al. Phase II study of pemetrexed and carboplatin plus bevacizumab as first-line therapy in malignant pleural mesothelioma. Br J Cancer. 2013;109(3): 552-558.

90. Papa S, Popat S, Shah R, et al. Phase 2 study of sorafenib in malignant mesothelioma previously treated with platinum-containing chemotherapy. J Thorac Oncol. 2013;8(6):783-787.

91. Dowell JE, Dunphy FR, Taub RN, et al. A multicenter phase II study of cisplatin, pemetrexed, and bevacizumab in patients with advanced malignant mesothelioma. Lung Cancer. 2012;77(3):567-571.

92. Jahan T, Gu L, Kratzke R, et al. Vatalanib in malignant mesothelioma: a phase II trial by the Cancer and Leukemia Group B (CALGB 30107). Lung Cancer. 2012;76(3):393-396.

93. Dudek AZ, Pang H, Kratzke RA, et al; Cancer and Leukemia Group B. Phase II study of dasatinib in patients with previously treated malignant mesothelioma (cancer and leukemia group B 30601): a brief report. J Thorac Oncol. 2012;7(4):755-759. 
94. Nowak AK, Millward MJ, Creaney J, et al. A phase II study of intermittent sunitinib malate as second-line therapy in progressive malignant pleural mesothelioma. J Thorac Oncol. 2012;7(9): 1449-1456.

95. Laurie SA, Gupta A, Chu Q, et al. Brief report: a phase II study of sunitinib in malignant pleural mesothelioma. the NCIC Clinical Trials Group. J Thorac Oncol. 2011;6(11):1950-1954.

96. Garland LL, Chansky K, Wozniak AJ, et al. Phase II study of cediranib in patients with malignant pleural mesothelioma: SWOG S0509. J Thorac Oncol. 2011;6(11):1938-1945.

97. Dubey S, Jänne PA, Krug L, et al. A phase II study of sorafenib in malignant mesothelioma: results of Cancer and Leukemia Group B 30307. J Thorac Oncol. 2010;5(10):1655-1661.

98. Mukohara T, Nagai S, Koshiji M, Yoshizawa K, Minami H. Phase I dose escalation and pharmacokinetic study of oral enzastaurin (LY317615) in advanced solid tumors. Cancer Sci. 2010;101(10): 2193-2199.
99. Tsao AS, Wistuba II, Mehran RJ, et al. Evaluation of Src Tyr419 as a predictive biomarker in a neoadjuvant trial using dasatinib in resectable malignant pleural mesothelioma. 2010 American Soceity of Clinical Oncology Annual Meeting; June 4-8, 2010; Chicago, IL. J Clin Oncol. 2010;28(15_suppl): Abstract \#7042.

100. Porta C, Mutti L, Tassi G. Negative results of an Italian Group for Mesothelioma (GIMe) pilot study of single-agent imatinib mesylate in malignant pleural mesothelioma. Cancer Chemother Pharmacol. 2007;59(1):149-150.

101. Mathy A, Baas P, Dalesio O, van Zandwijk N. Limited efficacy of imatinib mesylate in malignant mesothelioma: a phase II trial. Lung Cancer. 2005;50(1):83-86.

\section{Publish your work in this journal}

Cancer Management and Research is an international, peer-reviewed open access journal focusing on cancer research and the optimal use of preventative and integrated treatment interventions to achieve improved outcomes, enhanced survival and quality of life for the cancer patient The journal welcomes original research, clinical \& epidemiological studies, reviews \& evaluations, guidelines, expert opinion \& commentary, case reports \& extended reports. The manuscript management system is completely online and includes a very quick and fair peerreview system, which is all easy to use. Visit http://www.dovepress.com/ testimonials.php to read real quotes from published authors.

Submit your manuscript here: http://www.dovepress.com/cancer-management-and-research-journal 